\title{
INFORMATICS IN 21 TH CENTURY - REFLECTION OF CHANGES
}

\section{Vlasta RABE - Jan ŠLÉGR}

\begin{abstract}
This paper deals about reflection of changes in undestanding of teacher vocation and in teacher education focusused on informatics. Goal of this paper is monitoring of possibilities ICT and system approaches in education, especially focused on education future teachers in elementary and secondary schools. Nowadays education should develop skills for 21th century, i.e. orientation in ICT, problems solving, critical thinking and team working. It entails complex approach to education. Students are involved in projects and use their skills in inter-subjects relations - in mathematics, languages, geography, natural science and technologies. With ICT students use several technologies more effective, e.g. tool for planning, development or presentation of projects. Education should be joined with real world problems and practical exploitation of acquired knowledge and skills. collaborative learning and blended learning. There is accented pedagogical and psychological aspect of students motivation in engineering disciplins and ICT influence in development of key competences.
\end{abstract}

Key words: effective approach to teaching and learning, natural science, impact of ICT, motivation, key competences.

\section{INFORMATIKA V 21. STOLETÍ - REFLEXE PROMĚN}

Resumé: Př́spěvek je zaměřen na reflexi proměn v pojetí profese učitelství a ve vzdělávání učitelů se zaměřením na informatiku. Cílem př́spěvku je zamyšlení nad možnostmi efektivního využití ICT a systémových př́istupů ve výuce, zejména se zaměřením na přípravu budoucích učitelů ZŠ / SŠ. Dnešní vzdělávání musí podporovat rozvíjení schopností pro 21. století, jako např. dobrou orientaci ve využívání informačních a komunikačních technologií, schopnost řešení problémů, kritické myšlení a spolupráci v týmech. To znamená komplexní př́stup ke vzdělávání a nové nároky na profesi učitelství. Ve výuce je uplatňována projektová výuka, mezipředmětové vztahy - v matematice, jazycích, geografii, přírodních vědách a technologiích. ICT umožňuji studentům používat různé technologie efektivněji, jako nástroje pro plánování, vývoj nebo prezentaci projektů. Vzdělávání musí být spjato $\mathrm{s}$ problémy skutečného světa a s praktickým využitím nabytých znalostí a dovedností.

Kličcová slova: efektivní přistup k výuce a sebevzdělávání, přírodní vědy, vliv ICT, motivace, klíčové kompetence.

\section{1 Úvod}

Jedním z klíčových trendů učitelského vzdělávání v Evropě je výrazná profesionalizace učitelské profese a prípravy na ni. Jádrem profesionalizace je pojetí učitele jako facilitátora žákova vývoje a učení, který se snaží dovést každého žáka $\mathrm{k}$ jeho osobnímu maximu (vytváří vhodné podmínky $\mathrm{k}$ učení), pomáhá mu se orientovat, podněcuje, inspiruje, vybavuje pocitem kompetence, sebedůvěry. V tomto pojetí se výrazně posiluje i sebezodpovědnost studujícího za své výsledky a zároveň se zvětšují nároky na schopnost učitele analyzovat vlastní činnost, prezentovat a argumentovat své pojetí práce, diskutovat a spolupracovat s kolegy, rodiči i širším sociálním okolím (zejména spolupráce s rodiči se zatím jeví jako nefungující).

Model široké profesionality znamená hledání nové profesní identity učitele, založené na nových hodnotách učitelské profese a představuje tedy také silnou výzvu pro učitelské vzdělávání. Odpovědí na tyto výzvy jsou personalistická a konstruktivistická koncepce př́ipravy učitelů, které představují klíčová teoretická východiska současných proměn učitelského vzdělávání $\mathrm{v}$ celoevropském měřítku.

\section{Východiska pro transformaci učitelského vzdělávání}

Podle usnesení Lisabonského summitu v r. 2000 se Evropa měla do roku 2010 stát ,jednou $\quad z \quad$ nejkonkurenčnějších a nejdynamičtějších ekonomik ve světě, založenou na znalostech a schopnou trvale udržitelného růstu, s větším počtem lepších pracovních míst a s vyšší sociální soudržností.“. Je tomu opravdu tak?

$\mathrm{V}$ tomto společenském rámci musí i vzdělávání na základních, středních i vysokých školách v 21. století nutně měnit svou podobu. 
Vzdělávání úzce koresponduje $\mathrm{s}$ ekonomikou, projevuje se proaktivní prŕstup vzdělávacích institucí ke vzdělávání a výzkumu a vliv rychle se rozvíjejících informačních a komunikačních technologií. To vyžaduje větší flexibilitu a inovace. $\mathrm{Z}$ tohoto důvodu se jeví nutnost zaměrit pozornost na nové možnosti $\mathrm{v}$ oblasti vzdělávání $\mathrm{s}$ využitím dostupných prostředků ICT $\mathrm{s}$ posunem $\mathrm{k}$ otevřenému distančnímu vzdělávání, zejména na vysokých školách (Riedl, 2003).

\section{Nové nároky na profesi učitelství \\ $\mathbf{v}$ informační společnosti}

Výše uvedené koncepce kladou důraz na osobnostní a profesní růst, na individuální proces postupného „stávání se učitelem“, ve smyslu aktivního konstruování a tvořivého osvojování učitelské profese na základě vlastní činnosti, vlastních zkušeností, sebepoznávání, vlastního hledání a objevování ve spolupráci s kolegy a studenty.

Nutnost neustálého obnovování informací a znalostí vede univerzity $\mathrm{k}$ celoživotnímu vzdělávání, nebot' $\mathrm{v}$ informační společnosti se práce $\mathrm{s}$ informacemi a jejich sdílení a prezentace stává součástí každodenního života a studenti si uvědomují, že bude potřeba se školit nebo přeškolovat $\mathrm{v}$ různých obdobích jejich života. V relativně unikátních aplikacích přestává být „užitečný“ masově a uniformně vzdělaný pracovník, snadno zaměnitelný, ale naopak individuální pracovník, jehož znalosti a dovednosti jej činí jedinečným z hlediska dané činnosti. Postupně nahradíme termín „,vzdělání“ výstižnějším termínem „vzdělávání“, nebot' se jedná o kontinuální proces. Instituce vysokého vzdělávání by se měly snažit, aby se na tento trend připravily. Bude totiž $\mathrm{v}$ sobě zahrnovat zvýšenou míru školení, studia při zaměstnání, krátkých kurzů, nikoliv nutně s cílem získání titulu. Univerzity modifikují rozvrh a obsah učebních osnov. Mnoho studentů se už nezajímá o zkvalitňování oblasti vědy, ale o př́pravu na práci tím, že se soustředí na výsledné poznatky, $\mathrm{k}$ nimž věda dospěla. Př́prava na práci v současnosti vyžaduje především znalost různých disciplín, kombinovaných s dovednostmi a praktickým know-how. Naše univerzita se snaží vyjít vstříc uchazečům o studium $\mathrm{s}$ výhledem na další uplatnění formou specializovaných kurzů, exkurzí apod.

\section{ICT kompetence učitele}

Samotné technologie obvykle nejsou důvodem ke změně, mohou však dát podnět $\mathrm{k}$ realizaci předem nazrálých výukových inovací. Nestačí jen dodat do škol počítače, ale je potřeba změnit koncepci výuky vzhledem ke kreativnímu myšleni a schopnosti aplikovat získané vědomosti v praxi.

Kompetencemi učitele chápeme soubor profesních dovedností a dispozic, jimiž má být vybaven učitel, aby mohl vykonávat své povolání. Učitel, který aplikuje ICT nikoliv jen jako prostředek k prezentaci učiva, $\mathrm{k}$ demonstraci či tvorbě výukových materiálů, ale pomocí ICT skutečně vytváří edukační prostředí, již nevystačí se znalostmi z oboru a se základními poznatky psychologicko-didaktických disciplín, ale musí zvládat kromě tradičních dovedností dovednosti zcela nové. Jeho úloha se posouvá $\mathrm{z}$ role poskytovatele faktů, informací žákům na roli ř́zzení poznávacích a učebních aktivit žáků a na spolupráci se žáky a dalšími učiteli a odborníky. $\mathrm{V}$ době, kdy množství nových poznatků $\mathrm{z}$ různých oborů roste, není možné očekávat, že učitel bude vždy schopen vše vysvětlit, vyložit, najít odpověd' na každou otázku a problém. Učitel by měl však najít způsob a aplikovat takové metody, aby odpověd' na problém či otázku našel a žákům poskytl, a k tomu může využít právě ICT.

Schopnost práce $\mathrm{s}$ ICT je explicitně zmiňována jako součást tří oblastí: schopnosti učit se, matematických schopností a základních schopností $\mathrm{v}$ oblasti vědy a technologií a schopnosti práce $\mathrm{s}$ digitálními technologiemi (tj. technologiemi informační společnosti).

Požadované ICT kompetence zahrnují schopnost vyhledávat, shromažd'ovat a zpracovávat informace a používat je kritickým a systematickým způsobem, hodnotit jejich důležitost a rozlišovat mezi reálnými a virtuálními informacemi a zároveň chápat vztahy. Jedinci by měli umět používat nástroje k vytváření, prezentaci a pochopení komplexních informací a měli by být schopni internetové služby získávat, vyhledávat a používat; rovněž by měli umět používat informační technologie $\mathrm{k}$ podpoře kritického myšlení, tvořivosti a inovací.

Rozhodující pro výuku, v níž jsou kvalitním a plnohodnotným způsobem aplikovány ICT k edukačním aktivitám účastníků výuky, jsou kvality učitele $\mathrm{v}$ oblasti prípravy, realizace, monitorování a vyhodnocování výuky a vlastního 
řízení procesu učení žáků s efektivním využitím ICT (Černák, 2007).

Kompetence učitele aplikujícího ICT ve své každodenní práci:

- Odborné dovednosti a znalosti z oboru

- Pedagogické a manažerské dovednosti

a znalosti učitele potřebné pro výuku podporovanou ICT

- Informačně a komunikačně

technologické dovednosti učitele potřebné pro aplikování ICT ve výuce

- Jazykové kompetence - znalost aspoň jednoho cizího jazyka, především anglického

- Sociálně komunikativní kompetence

\section{Změna role učitele}

Nedílnou součástí tohoto procesu je změna role učitele, a to od přenosu znalostí $\mathrm{k}$ přemýšlivému učení, poznání, jak se studenti učí a za jakým účelem. (V současnosti se prosazující teorie konstruktivního vyučování předpokládá změnu role učitele. Jeho hlavním úkolem již není vědět vše, ale vytvářet prostředí, v němž mají studenti vlastní zájem o učení.) Existuje rostoucí pohyb vzdělávacích procesů od učitele $\mathrm{v}$ centru zájmu, $\mathrm{k}$ procesům, $\mathrm{v}$ nichž je centrem zájmu student. Autorita učitele z hlediska věrohodnosti předávaných znalostí $\mathrm{a}$ informací bude $\mathrm{v}$ mnohem větší míře muset odrážet pluralitu informačních zdrojů, které studenti budou mít k dispozici (Riel, 2000). Počítačové sítě a informační služby typu celosvětové informační sítě WWW na Internetu nabízejí mnohem širší informační základnu, ze které lze čerpat, než tomu bylo kdykoli v minulosti, poskytují prostředí, které obsahuje i multimediální prvky, na rozdíl od tištěné podoby. Jedním $\mathrm{z}$ podstatných úkolů učitele odborných předmětů je vysvětlovat teoretický obsah v různých souvislostech, v nějaké prakticky navozené situaci, která simuluje aspekty skutečného světa, se zaměřením na budoucí práci studentů. Studenti pak jsou schopni reagovat na nové skutečnosti a vyvíjet nové koncepty, opětovně používat nabyté zkušenosti pro snadnější porozumění novým problémům, a aplikovat efektivně současné produkty ICT ve výzkumu a vývoji. Zároveň tak dobře porozumějí vyučované disciplíně a přitom se stanou profesionály $\mathrm{v}$ oblasti informatiky. Je kladen důraz na praktické vyučování a učení se jako nástroje pro implementaci metody „learning by doing“ (učení činností), spolu s „experiential learning“ (zkušenostním učením), (Rabe, 2008).

\section{Trendy systémové komplexní péče o učitelskou profesi}

Východiskem pro změny ve vyučovacím procesu $\mathrm{v}$ prostředí nové ekonomiky založené na znalostech je proaktivní př́istup ke vzdělávání a výzkumu. Výukové aktivity, ve většině príípadů podporované ICT, se zaměřují zejména na inovativní metody ve výuce. V informační společnosti je nezbytné rozvíjet informatickou výchovu ve všech oborech,na všech úrovních vzdělávání. Informatickou výchovu a vzdělávání je třeba chápat jako dlouhodobý proces vedoucí $\mathrm{k}$ informačně gramotné společnosti. Jedná se tedy o rozvoj všech funkčních gramotností, jak informační a počítačové, tak i literární, dokumentové, numerické a jazykové, a jejich vzájemného propojení. V této souvislosti lze chápat informační gramotnost jako o jednu z klíčových kompetencí v informační společnosti.

Učitel ve společnosti znalostí má být klíčovým činitelem ve všech strategických postupech zaměřených na podporu rozvoje společnosti a ekonomiky (zasedání Evropské rady, Barcelona 2003).

Strategie, která má zajistit systémovou a komplexní péči o učitelskou profesi, musí vyvinout sedm následujících reformních trendů (Z. Helus, konference Učitel 21, Praha 2008):

1) Zaštítění nezpochybnitelnosti učitelského vzdělání na magisterské úrovni jako nezbytné podmínky výkonu profese. Činnost: výuka, rozvoj školy,vybavení učitele pro komunikaci (primární partnerství), sekundární partnerství (s MŠMT, ...), politický kontext, vztah učitele k sobě samému

2) Vypracování a prosazení rámcových standardů učitelského vzdělávání. RVP, zajištění znalostí a kompetencí (důraz na pregraduální vzdělávání), odhalování variant řešení a jejich obhájení, ...

3) Vybudování fakultních škol pedagogických laboratoří /klinik k účinnému vyučování učitelů a úspěšnému učení žáků .

4) Vytvoření grantů na podporu učitelství. Základní i aplikační výzkum

5) Diferenciace učitelů. Modely, ...

6) Opora, pomoc. Poradenství, konzultační centra

7) Samosprávnost učitelů. 
Učitelé musí sami prosazovat své nároky ale být si vědomi své plné zodpovědnosti.

\section{Standard kvality profese učitele}

(Vypracovala Pracovní skupina pro tvorbu standardu. MŠMT,16.3.2009, www.msmt.cz)

Standard by měl zajistit profesionalitu pedagogů $\mathrm{z}$ následujících hledisek:

- profesní růst

- podpora

- pravidla

- podmínky

- peníze

- poctivost

- př́ležitost

Není cílem tohoto článku rozebírat výše uvedený standard. Podle mého názoru ale nelze šablonovitě hodnotit pedagoga podle počtu publikací $\mathrm{v}$ impaktovaných časopisech nebo hodnotit kvalitu školy podle pořadí $\mathrm{v}$ žebrríčcích. Standardy se mohou stát vodítkem ale nikoliv zárukou kvality učitele. Současná společnost vyžaduje komplexní změnu přístupů ke své práci, sebezodpovědnost a změnu stylu myšlení.

\section{Závěr}

Mnoho studií dokazuje, že informační a komunikační technologie samy o sobě nemohou rapidně zlepšit vzdělávací proces. Důležitou roli hraje začlenění a způsob využivání $\mathrm{v}$ různých učebních aktivitách. Role učitele je $\mathrm{v}$ tomto procesu nezaměnitelná, učitel vytváří interaktivní prostředí se zpětnou vazbou od studentů a podporuje jejich aktivní učení.

Informační a komunikační technologie mají značný vliv na současný vývoj výukových metod. $\mathrm{V}$ současné době převládá snaha zapojovat technologie do výuky spíše konstruktivním způsobem. Př́ínos technologií spočívá především v urychlování a umocňování výukových procesů. To, jakým způsobem budou technologie použity, závisí ve velké míře na znalostech, schopnostech, a př́stupu učitelů. Jejich úkolem je výukové využití technologií správným způsobem nasměrovat.

\section{Literatura}

[1] BELZ, H., SIEGRIEST, M. Klíčové kompetence a jejich rozvíjení. Praha, Portál 2001. [2] PASCH, M. Od vzdělávacího programu k vyučovací hodině. Praha: Portál, 1998.

[3] MORGAN, A. Improving your Students' Learning: reflections on the experience of study, London, 1993.

[4] PRŮCHA, J. Moderní pedagogika. Praha: Portál, 1997.

[5] SENGE, P. The Art and Practise of the Learning Organization, Doubleday, N.Y.,1990

[6] RIEDL, A. Didaktik II - Berufliche Bildung. München : Technische Universität, 2003.

[7] RIEL, M. The future of technology and education: Where are we heading? in: Watson, D. M. \& Downes, T. (Eds.) Communications and Networking in Education. Boston, MA: Kluwer Academic Press, 2000, pp 9-24.

[8] ČERMÁK, I., MAŠEK, E. Základy elektronického vzdelávania. Vysokoškolská učebnice, Ružomberok 2007. s.343, ISBN 97880-8084-1713.

[9] SUTERLAND, R. Designs for learning: ICT and knowledge in the classroom. Computers and Education, 2004, Volume 43 , Issue 1-2. ISSN:0360-1315.

[10] RABE, V., JEHLIČKA, V. E-learning and blended learning at the university. ED-MEDIA, Vienna, 2008, ISBN: 1-880094-62-2.

Mgr. Vlasta Rabe, Ph.D.

Katedra informatiky

Mgr. Jan Šlégr

Katedra fyziky

Př́rodovědecká fakulta UHK

Rokitanského 62

50003, Hradec Králové, ČR

Tel: +420 4933311170

E-mail: vlasta.rabe@uhk.cz, jan.slegr@uhk.cz

Www pracovišstě: $\underline{\text { ww.uhk.cz }}$ 